\title{
A study on the role of love to in the character building of army soldiers in Indonesia
}

Zainal Abidin Ike, Aulia

Universitas Ahmad Dahlan, Indonesia (auliazenlovemail@gmail.com)

Sulisworo, Dwi $\bowtie$

Universitas Ahmad Dahlan, Indonesia (dwi.sulisworo@uad.ac.id)

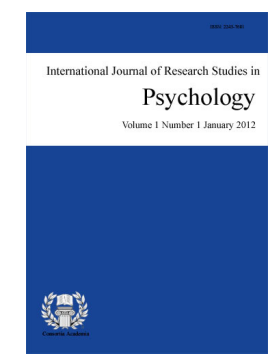

ISSN: $2243-7681$ Online ISSN: 2243-769X

OPEN ACCESS

\section{Abstract}

Love and job are firstly two separated study objects, but when it is brought to the human life context, the two things could not be easily separated. This perspective explains that job and love can be united because they are in the different world. Now days, the dynamics of love on the job becomes an interesting topic to study considering that so far the explanation on that construction is still not enough. This research focuses on love on the job in the military organization setting. The consideration is based on the fact that theoretically psychological study on the job love in the military setting has never been conducted. The research subjects are six soldiers of Indonesian National Armed Land Forces assigned at Military Academy at Magelang, Indonesia. The verification of concept consistency in this research uses theoretical saturation. Research data is collected through observation, documentation, and in-depth face to face interview to the six research subjects. Based on the result of the conducted research, it can be concluded that the formation of love on the job in the military starts unconsciously from the education process experienced by the candidate of the soldier. The doctrine got during the education to change the mindset from a civilian to an army gives a big contribution to build the character of discipline, solidarity, and responsibility of the soldier candidates.

Keywords: army; doctrine; love; psychology; Indonesia 


\section{A study on the role of love to in the character building of army soldiers in Indonesia}

\section{Introduction}

Ashkanasy (2003) explained the current development of the research on emotion in all levels of organization analysis, and one of the researches on emotion shows that love has a big influence on the human psychological wellbeing. However, how does love relate to work? Are they connected? Since a long time ago, Hazan and Shaver have presented this question in the context of research program on love and job (Hazan \& Shaver, 1987; Shaver, Hazan, \& Bradshaw, 1988), which they have learned based on attachment theory perspective (Bowlby, 1973; 1980). It is said that love and job are basically two important things in the human's life, as Tolstoy (as cited in Troyat, 2001) stated in his letter to Valerya Arsenev on November 09, 1856, one can live magnificently in this world if one knows how to work and how to love. Tolstoy's expression (as cited in Troyat, 2001) and Gibran (1969) conforms what McClelland (1965); Maslow (1970); Hulin (2002) and other experts such as Herzberg, Mausner, and Snyderman (1993) stated; which acknowledge that if one doesn't consider his job meaningful and as the life goal, he will never work in his highest professional capacity

Love and job are firstly two separated study objects, but when it is brought to the human life context, the two things could not be easily separated. This assumption doesn't conform what Kanter (1977) stated when he mentioned love and job as separated world myths. This perspective explains that job and love can be united because they are in the different world. Kanter's perspective that was acknowledged in his era was finally refuted by the existence of the current research findings. However, the first objection to Kanter's perspective was delivered by Hazan and Shaver (1990) who conducted a research on the job love for the first time by using attachment perspective. Through the result of their research, Hazan and Shaver (1990) explain that love and job couldn't be easily separated if they are in the social context of human's life. Hazan and Shaver (1990) through the thinking view suggest the attachment theory could be used to naturally connect love and work. Therefore, adult work activity can be viewed as having the same function as what Bowlby said which was exploration; for adult, working (as playing and exploration context for the early child) is the main source of actual competence.

Next, current finding especially in 2000s era shows that love has important meaning in the workplace. Many people deeply involve in their job because of love, especially if they come from middle class family and or they are academic-oriented (Arnett, 2000; Osgood, Ruth, Eccles, Jacobs, \& Barber, 2005; Shulman \& Nurmi, 2010). Happiness in working is an experience when one works actively and comprehensively by using their skills. In addition, what it feels when founding the suitable and enjoyable job is considered as a very fundamental thing for someone. On the research conducted by Uusiautti and Määttä (2011), they studied various dimensions of love on the job and how it can be developed. They explain that love means a deep care to other people and it creates a proper life. In other words, love is a strong affective emotion and an individual attachment to the attached object.

Based on the previous explanation, ideas about love on the job have been researched by the previous organization researchers. Now days, the dynamics of love on the job becomes an interesting topic to study by the researcher considering that so far the explanation on that construction is still not enough. Therefore, based on some considerations, this research focuses on love on the job in the military organization setting. The consideration is based on the fact that theoretically psychological study on the job love in the military setting has never been conducted.

Another consideration is that military is an important organ in the Republic of Indonesia. Muhaimin (2005) stated that military is one of the important organs that a government of a country should have because the military is a group of people who differ from civilian and are organized with the discipline to fight. It means military, in this context Indonesian National Armed Forces, is the main component to conduct a military operation duty on war and other military operations. 
A study on the role of love to in the character building of army soldiers in Indonesia

It shows that task of Indonesian National Armed Forces soldiers is not easy. It is a task that needs big and sincere sacrifice, as stated in the article 35 of Law number 34 Year 2014 on Indonesian National Armed Forces and mentioned on the soldier oath that Indonesian national Armed Forces soldiers are demanded to carry out their task totally. It means soldiers who are only patchy or don't have passion and love on their jobs may have a hard time to carry out their task. Further, obstruction and difficulty which are not well solved will result in the unsatisfaction, low performance, even turnover. However, with the existence of love on the job as a soldier, the soldiers are expected to feel comfortable, meaningful, and wealthy in doing their task and job, although in the limited or impossible condition.

Last but not least, a research on love on the job, especially in the Indonesian National Armed Forces is assumed to have big possibility to be brought to the study context of organizational psychology, especially military organization, in this research Indonesian National Armed Forces. This research aims to explore the concept of love on the job through the perspective of Indonesian National Armed Forces soldier, so a deep understanding of love on the job based on what is experienced by Indonesian National Armed Forces soldiers can be obtained.

\section{Methodology}

The research subjects are six soldiers of Indonesian National Armed Land Forces assigned at Military Academy at Magelang, Indonesia. The verification of concept consistency in this research uses theoretical saturation (Strauss \& Corbin, 1998). Theoretical saturation is by using general rule that to build theory data must be collected till each category (theme) is saturated. It means from each data input, coding, categorization, and concept analysis are directly conducted, so the subjects are considered enough if the data informing concept consistency is saturated. Therefore, the use of six data sources is considered as having followed the rule in grounded theory that data collected based on each category/theme has been saturated.

Research data is collected through observation, documentation, and in-depth face to face interview to the six research subjects. The interview is guided by research questions, but it is unstructured so it is possible to find new idea or theme. The guidance is modified by the researcher during the process of data collection to complete the result of the research that doesn't give information as wanted. Next, it is to reflect the category and concept which need further development (Strauss \& Corbin, 1998).

The interview data is recorded by using tape recorder under the research subjects concern. Then the transcript with verbatim is arranged and analyzed. Data analysis used in this research is grounded theory study from Strauss and Corbin (2007) which includes open coding, axial coding, and selective coding phase.

\section{Results and discussions}

\subsection{The dynamics of love on the job}

Soldiers basically work based on the duty call. The duty call here relates to all orders from the commandant those are compulsory to execute according to the Sapta Marga and the soldier oath. When working; a soldier has only two choices, which are executing the orders or rejecting and get punishment. This figure of the work situation which tends to a rationality element finally views love of a soldier on his job as pseudo-love. The concept of love on the job of a soldier is only like a secure attachment from Hazan and Shaver (1990), where the person is considered to feel insecure if he is not close to the job or ignored by the organization, so to handle the insecure feeling, the person tend to depend on themselves to the job/ organization. In other words, pseudo-love is because the person's love only refers to a continued commitment from Meyer and Allen (1991), that person's commitment relates to the consideration of loss got by the person if he leaves the organization such as financial loss, position, power, promotion, and others. It means leaving the organization becomes a high-risk action because the person is afraid of loss and realizes that they couldn't find the replacement. However, in the fact, the 
result of the research shows that person's love on his job is not merely because there are no other choices besides executing or rejecting the orders. At the end, happiness, closeness, and pride are got by them for the deeper internalization process of what they experience during their duty.

Based on the result of the research, what love on the job means for the person is the feeling of happiness, closeness, and pride on the job which are shown through sacrifice by giving the best to execute the orders commanded by the commandant or the organization. This concept of love doesn't refer to the individual need fulfillment, but their dedication and sacrifice to the organization and country. It is because they work not only for individual need fulfillment, parents or family but also they want to contribute in protecting the motherland through the organization or task they work on. Thus, this concept of love on the job is similar to the concept of being love delivered by Maslow (1970); dedication in the engagement context delivered by Schaufeli (2002; 2006); and the concept of Kenosis (self-emptying) from Almond (2008). What being love means is love that doesn't focus on oneself, but showing care to other's need, in this case, is corps/organization.

Next, the dedication concept means the condition when one feels involved, enthusiastic, proud, meaningful, inspired and challenged in doing his duty, while the concept of Kenosis relates to individual self-emptying such as the subjective feeling of the need to self-sacrifice as the expression of love on the job.

\subsection{The formation process of love on the job}

The formation of love on the job in the military starts unconsciously from the education process experienced by the candidate of the soldier. The doctrine got during the education to change the mindset from a civilian to an army gives a big contribution to build the character of the soldier candidates. Special values of military culture such as discipline, solidarity, and responsibility instilled during the education, in fact, have a big and important influence on the work attitude of the soldier candidates when on duty. The duty call that can't be rejected and must be executed, feels hard in the beginning. Therefore, in the beginning a person may only do his duty to fulfill the obligation and avoid punishment. However, as the time passes, through the task burden, challenge and demand in any situation and condition, the soldiers experience the internalization process deeper and deeper to their job. In this case, to make the order commanded by the commandant feels easier and can get the maximal result, the soldier decides to view and do the duty happily, sincerely and willingly. As Hochschild (1983) stated that feeling mechanism can be activated by the deep assignment where the personal consciously try to really feel the emotion they need in the workplace. In addition, it can't happen by itself. The personal consider that what they do can't be separated from the existed support system.

This support system comes from the organization (senior, junior or partner) and family (wife and children), where positive support from the organization and family has a big influence for increasing enthusiasm and performance of the personal. According to Hatfield, Cacioppo, and Rapson (1993) experience of the personal, the way to create sincere love among the employees in the collective setting is through emotion spreading/ influence. A personal catches the companionate love emotion from the organization through partners, seniors or juniors in form of ceremony, education (training, exercises, achievement, capacity, career) and active supervision. In addition from the wife or children, it can be in form of wife participation at Soldier Wife Association or support the spouse for the official duty given as a soldier.

Spreading, in this case, is an unconscious process where most personal truly feel the emotions they catch from the environment and see them as theirs. This happens through feedback of the attitude and hearing: after imitating other's expression, intonation, or gesture, individual expression or actions which push feeling (Strack, Martin, \& Stepper, 1988; Hatfield, 1988). A research conducted by Barsade, Ward, Turner, and Sonnenfeld (2000) found that workgroup with the low positive emotion experience more significant emotional burden and conflict and less group cooperation and cohesiveness compared to another group with high positive emotion. This founding conforms to what Barsade (2002) found that positive emotion spreading within a group relates to the improvement of work performance, cooperation and the decrease of conflict. Thus, positive emotion is an 
important sign of the group cohesiveness and productivity.

In the context of workgroup organization, George (1990) showed that positive affection is the main key to the group effectiveness and satisfaction (also see George \& Brief, 1992). Lawler, Thye, and Yoon (2002) also found that positive emotion unifies and strengthens the relation of a person to the group and decrease the uncertainty, as the result it can increase the commitment to the goal of work team, while the negative impacts are decreasing the team cohesion, motivation and may disturb performance.

It means the closeness process can be internalized in the personality structure at the individual level and can influence one's character and his interaction in the workplace and organization environment. Positive perception of oneself, other, and environment during working based on the closeness offer with two main forms of the working model are; working model on other and on oneself. Therefore, positive scheme owned by one toward oneself, other or environment is a strengthener that continuously occurs through a series of self-fulfillment (Hazan \& Shaver, 1987). Therefore, internalization process that is not positively construed by the personal can cause the violation, even desertion. In opposite, if it is positively construed by the personal, it can change pseudo-love to the true love. A Javanese proverb says "witing tresno jalaran sokokulino" which means "Love grows because it is wont". Thus, love the job which personal feels as happy, close and proud feeling on the job, which is then shown by sincerely sacrificing and giving the best to execute the order from the commandant or the organization conforms to Stenberg's (1986) concept of commitment dimension of love triangle that relates to the cognitive element, that personal has decided to choose a job as a soldier and to defend that relationship. Therefore, the less commitment of the person for a long time can distract the relationship between the personal and the organization.

The soldier commitment to their job is conceptually similar to effective and normative commitment dimension from Meyer and Allen (1991), where the personal consciously consider their own interest and organization interest because they want it (effective); in addition the existence of compulsory feeling to stay at the organization because it considers a correct action to do (normative). Therefore, the person who loves their job will consider their job everything, so it will feel empty, lost, confused and different when they don't work. They will also feel satisfied if they successfully and maximally finish their duty and feel disappointed if they fail to finish their duty. It means soldiers who love their job can be seen from their work attitude.

\subsection{Outcome of love on the job}

Soldiers who love their job will show their love by improving discipline, work performance, OCB, commitment, integrity and skill in working. Discipline means obedient, not violating the official rule, keeping the good image of the military unit/ organizations, becoming a good example for the junior, not opposing the order, always getting ready to execute all orders commanded no matter how difficult it is or they are not able to finish it. Every soldier of Indonesian National Armed Forces must submit and obey every law rule applied for military based on Military Criminal Code. This military law is applied to enlisted, non-commissioned officer, and officers who harm the military unit, society, and country regarding the other rules applied for general society. Work ethos means enthusiastic, executing the order cheerily, sincerely, and sacrificially, finishing the task seriously to give the best and maximal result. Organizational Citizenship Behaviour (OCB) means giving the idea, solution to partner or senior to finish the duty, and helping partner in the team when they can't attend without any repayment from senior or organization. Commitment means consistently give the trust to the senior, consequent in executing the order, showing it through performance, having no eager to leave the job or organization. Integrity means reliable and truthful, in this case getting ready to bear any risks of the orders commanded as the response to the commandant and organization. Skill means being able to finish and carry out a position, willing to improve the knowledge or skills by education and finding a solution from other partners or experts to finish a task. 


\section{Conclusion}

Based on the result of the conducted research, it can be concluded that the formation of love on the job in the military starts unconsciously from the education process experienced by the candidate of the soldier. The doctrine got during the education to change the mindset from a civilian to an army gives a big contribution to build the character of discipline, solidarity, and responsibility of the soldier candidates. Pseudo love can occur if a personal executes the order commanded only to fulfill his obligation or to avoid punishment. Love on the job means the feeling of happiness, closeness, and pride on the job shown by sincerely sacrificing and giving the best to finish the task commanded by the commandant or the organization. Support system from the organization through the senior, junior or partner; and families such as wife and children have a very big influence in the process of internalization to form positive emotion of the person to mean the true love on the job. Soldiers who love their job will show their love by improving discipline, work performance, OCB, commitment, integrity and skill in working.

\section{References}

Arnett, J. J. (2000). Emerging adulthood: A theory of development from the late teens through the twenties. American Psychologist, 55(5), 469-480. https://doi.org/10.1037/0003-066X.55.5.469

Ashkanasy, N. M. (2003). Emotions in organizations: A multi-level perspective. In Multi-level issues in organizational behavior and strategy (pp. 9-54). Emerald Group Publishing Limited. https://doi.org/10.1016/S1475-9144(03)02002-2

Barsade, S. G. (2002). The ripple effect: Emotional contagion and its influence on group behavior. Administrative Science Quarterly, 47, 644-675. https://doi.org/10.2307/3094912

Bowlby, J. (1973). Attachment and loss: Separation: Anxiety and anger (Vol. 2). New York: Basic Books.

Bowlby, J. (1980). Attachment and loss: Sadness and depression (Vol. 3). New York: Basic Books.

George, J. M. (1990). Personality, affect, and behavior in groups. Journal of Applied Psychology, 75,107-116. https://doi.org/10.1037/0021-9010.75.2.107

George, J. M., \& Brief, A. P. (1992). Feeling good-doing good: A conceptual analysis of the mood at work-organizational spontaneity relationship. Psychological Bulletin, 112(2), 310-329. https://doi.org/10.1037/0033-2909.112.2.310

Gibran, K. (1969). The prophet. New York: Alfred A. Knopf, Inc.

Hatfield, E. (1988). Passionate and Companionate Love. In R. Sternberg \& M. Barnes (Eds.), The psychology of love (pp. 191-217). New Haven, CT: Yale University Press.

Hatfield, E., Cacioppo, J. T., \& Rapson, R. L. (1993). Emotional contagion. Current Directions in Psychological Science, 2(3), 96-100. https://doi.org/10.1111/1467-8721.ep10770953

Hazan, C., \& Shaver, P. (1987). Romantic love conceptualized as an attachment process. Journal of Personality and Social Psychology, 52, 511-524. https://doi.org/10.1037/0022-3514.52.3.511

Hazan, C., \& Shaver, P. R. (1990). Love and work an attachment-theoretical perspective. Journal of Personality and Social Psychology, 59(2), 270-280. https://doi.org/10.1037/0022-3514.59.2.270

Herzberg, F., Mausner, B., \& Snyderman, B. (1993).The motivation to work (2nd ed.). New York: John Wiley. Hochschild, A. R. (1983). The managed heart. Berkeley.

Hulin, C. L. (2002). Lessons from industrial and organizational psychology. In J. M. Brett \& F. Drasgow (Eds.), The psychology of work: Theoretically based empirical research (pp. 3-22). New York: Lawrence Erlbaum Associates, Inc., Publishers

Kanter R. M. (1977). Work and family in the United States: A critical review and agenda for research and policy. New York: Sage.

Lawler, E. J., Thye, S. R., \& Yoon, J. (2000). Emotion and group cohesion in productive exchange. American Journal of Sociology, 106(3), 616-657. https://doi.org/10.1086/318965

Maslow, A. H. (1970). Motivation and personality (2nd ed.). New York: Harper \& Row.

McClelland, D. C. (1965).Toward a theory of motive acquisition. American Psychologist, 20, 321-333. 
A study on the role of love to in the character building of army soldiers in Indonesia

https://doi.org/10.1037/h0022225

Meyer, J. P., \& Allen, N. J. (1991). A three-component conceptualization of organizational commitment. Human Resource Management Review, 1(1), 61-89. https://doi.org/10.1016/1053-4822(91)90011-Z

Muhaimin, Y. A. (2005). The development of military in the politics in Indonesia 1945-1966 [Perkembangan Militer dalam Politik di Indonesia 1945-1966]. Yogyakarta: Gadjah Mada University Press.

Osgood, D. W., Ruth, G., Eccles, J. S., Jacobs, J. E., \& Barber, B. L. (2005). Six paths to adulthood: Fast starters, parents without careers, educated partners, working singles, and slow starters. In R. A. Settersten Jr., F. F. Furstenberg Jr., \& R. G. Rumbaut (Eds.), On the frontier of adulthood: Theory, research, and public policy (pp. 320-355). Chicago, IL: University of Chicago Press. https://doi.org/10.7208/chicago/9780226748924.003.0010

Schaufeli, W. B., Bakker, A. B., \& Salanova, M. (2006). The measurement of work engagement with a short questionnaire a cross-national study. Educational and Psychological Measurement, 66(4), 701-716. https://doi.org/10.1177/0013164405282471

Schaufeli, W.B., Salanova, M., González-Romá, V., \& Bakker, A. B. (2002). The measurement of Engagement and burnout: A confirmative analytic approach. Journal of Happiness Studies, 3, 71-92. https://doi.org/10.1023/A:1015630930326

Shaver, P. R., Hazan, C., \& Bradshaw, D. (1988). Love as attachment: The integration of three behavioral systems. In R. J. Sternberg \& M. L. Barnes (Eds.), The psychology of love (pp. 68-99). New Haven, CT: Yale University Press.

Shulman, S., \& Nurmi, J. (2010). Dynamics of goal pursuit and personality make-up among emerging adults: Typology, change over time, and adaptation. New Directions for Child and Adolescent Development, 130, 57-70. https://doi.org/10.1002/cd.281

Sternberg, R. J. (1986). A triangular theory of love. Psychological Review, 93, 119-135. https://doi.org/10.1037/0033-295X.93.2.119

Strack, F., Martin, L. L., \& Stepper, S. (1988). Inhibiting and facilitating conditions of the human smile: A nonobtrusive test of the facial feedback hypothesis. Journal of Personality and Social Psychology, 54(5), 768. https://doi.org/10.1037/0022-3514.54.5.768

Strauss, A., \& Corbin, J. (1998). Basics of qualitative research techniques. Sage publications.

Strauss, A., \& Corbin, J. (2007). Basic of qualitative research: Grounded theory procedures and technique. Newbury Park: Sage Publications.

Troyat, H. (2001). Tolstoy. Retrieved from https://books.google.co.id

Uusiautti, S., \& Määttä, K. (2011). Love for work as the way towards wellbeing. Global Journal of Human Social Science, 11(9), 62-68. 
Zainal Abidin Ike, A., \& Sulisworo, D. 